\title{
The effect of nutrient fortification of sauces on product stability, sensory properties and subsequent liking by older adults
}

Article

Accepted Version

Tsikritzi, R., Wang, J., Collins, V. J., Allen, V. J., Mavrommatis, Y., Moynihan, P. J., Gosney, M. A., Kennedy, O. B. and Methven, L. (2015) The effect of nutrient fortification of sauces on product stability, sensory properties and subsequent liking by older adults. Journal of Food Science, 80 (5). S1100S1110. ISSN 0022-1147 doi: https://doi.org/10.1111/17503841.12850 Available at https://centaur.reading.ac.uk/39480/

It is advisable to refer to the publisher's version if you intend to cite from the work. See Guidance on citing.

To link to this article DOI: http://dx.doi.org/10.1111/1750-3841.12850

Publisher: Wiley

All outputs in CentAUR are protected by Intellectual Property Rights law, including copyright law. Copyright and IPR is retained by the creators or other copyright holders. Terms and conditions for use of this material are defined in the End User Agreement. 


\section{www.reading.ac.uk/centaur}

\section{CentAUR}

Central Archive at the University of Reading

Reading's research outputs online 
1 The effect of nutrient fortification of sauces on product stability, sensory properties and

2 subsequent liking by older adults

3 Roussa Tsikritzi ${ }^{a}$, Jianqiu Wang $^{a}$, Vanessa J.Collins ${ }^{a}$, Victoria J. Allen ${ }^{d}$, Yiannis Mavrommatis ${ }^{b}$,

4 Paula J Moynihan ${ }^{c}$, Margot A Gosney ${ }^{d}$, Orla B Kennedy ${ }^{a}$, Lisa Methven ${ }^{a^{*}}$

${ }^{a}$ Department of Food and Nutritional Sciences, University of Reading, Whiteknights, Reading RG6 $6 A P, U K$

${ }^{b}$ School of Sport, Health and Applied Science, St Mary's University College, Waldegrave Road, Twickenham, London,TW1 4SX, UK

${ }^{c}$ Institute for Ageing and Health, Newcastle University, Framlington Place, Newcastle upon Tyne, $N E 24 B W, U K$

${ }^{d}$ Clinical Health Sciences, University of Reading, London Road, Reading, Berkshire, RG1 5AQ, UK

* Corresponding author at: Department of Food and Nutritional Sciences, University of Reading, Whiteknights, PO Box 226, Reading, Berkshire RG6 6AP, UK. Email 1.methven@reading.ac.uk; Fax +44 (0) 118378 7708; Telephone +44 (0) 1183788714

\section{Intended section : Sensory and Food Quality}

Word Count : 6302

Short Title: Fortified sauces for older patients 
Abstract

There are potential nutritional and sensory benefits of adding sauces to hospital meals. The aim of this study was to develop nutrient fortified sauces with acceptable sensory properties suitable for older people at risk of under-nutrition. Tomato, gravy and white sauce were fortified with macro and micro-nutrients using food ingredients rich in energy and protein as well as vitamin and mineral premixes. Sensory profile was assessed by a trained panel. Hedonic liking of fortified compared with standard sauces was evaluated by healthy older volunteers. The fortified sauces had higher nutritional value than the conventional ones, for example the energy content of the fortified tomato, white sauce and gravy formulations were increased between 2.5 and 4 fold compared to their control formulations. Healthy older consumers preferred the fortified tomato sauce compared with unfortified. There were no significant differences in liking between the fortified and standard option for gravy. There were limitations in the extent of fortification with protein, potassium and magnesium, as excessive inclusion resulted in bitterness, undesired flavours or textural issues. This was particularly marked in the white sauce to the extent that their sensory characteristics were not sufficiently optimised for hedonic testing. It is proposed that the development of fortified sauces is a simple approach to improving energy intake for hospitalised older people, both through the nutrient composition of the sauce itself and due to the benefits of increasing sensorial taste and lubrication in the mouth.

Keywords: malnutrition, micronutrient, macronutrient, fortification, older people Practical Applications:

This study developed macro- and micro- nutrient fortified sauces where the intended use is for older adults at risk of under-nutrition. The energy content was increased between 2.5 and 
white sauces. We note that excessive protein addition leads to textural issues and excessive potassium or magnesium inclusion results in undesired flavours. We propose that fortified sauces are a simple approach to improving energy intake for hospitalised older people.

\section{Introduction}

Older people (>65 years) often do not consume enough energy and / or nutrients to support their minimum requirements. Current estimates suggest that undernutrition affects 1.3 million of people over 65 years of age in the UK (BAPEN 2011). This under-nutrition has been well documented to be associated with increased incidence of complications, longer hospital stays, reduced mobility, increased social isolation and reduced quality of life, and affects not only the older person, but also impacts on community and health service resources (Cowan and others 2004).

Maximising food intake is important for prevention and treatment of malnutrition, and this is sometimes difficult due to small appetite. One way of overcoming a small appetite is to fortify foods. Nutrient fortification can refer to the addition of either macronutrients or micronutrients to foods; or merely the addition of suitable condiments, such as a sauce, to foods. Previous studies have reported that the addition of sauces to a meal increased energy intake in older adults without affecting pre-meal hunger, desire to eat, or post-meal pleasantness (Appleton 2009). The increased energy consumption was mainly from fat and protein.

Within hospitalised older adults, it has been reported that meal macronutrient fortification can improve energy $(+26 \%)$ and protein $(+23 \%)$ intake (Gall 1998). When considering how to increase protein levels in foods for older people, both protein level and 
found that whey protein stimulates muscle protein synthesis more effectively than casein or vegetable protein (Pennings and others 2011) .

Best and Appleton (2011) found that the addition of both seasoning and sauce to an older person's meal resulted in comparable increases in energy, protein and fat intake, thus supporting a role for flavour enhancement in increasing the food intake of older people, as well as the role of the sauce itself. However, sauces may be more beneficial than dry seasonings when promoting food intake in older people due to the semi-solid nature of the sauce. In older individuals, where gastro-intestinal secretions and motility are known to be reduced or impaired (Cowan 2004), semi-solid foods may facilitate chewing and swallowing and aid the passage of foods through the digestive system (Appleton 2009).

\subsection{Micronutrient fortification}

Older hospital patients may be at risk of micronutrient deficiency due to low food intake, chronic diseases or medication (Bates and others1999). Moreover, eating micronutrient-dense foods becomes increasingly important where appetite is small but vitamin and mineral needs remain high.

Considering the development of micronutrient fortified foods for older hospital patients, two approaches could be taken. One approach would be to provide a "full" nutrient supplement, the principle taken by oral nutritional supplement (ONS) beverages. An alternative approach, and the one taken in this study, is to fortify products with micronutrients for which there is substantial evidence within the older adult institutionalised community.

Evidence from the UK National Diet and Nutrition Survey (NDNS) indicates that the micronutrients that institutionalised older people are most likely to be at risk of deficiency of are iron, vitamin D, riboflavin, folate and vitamin C (Bates and others 1999). The study by Bates and others (1999) considered micronutrients where intake was low (more than $25 \%$ of institutionalised participants with intakes below the RNI) or where more than $25 \%$ of 
institutionalised participants had biochemical indices low enough to be associated with deficiency. More recently the Food Standards Agency (FSA) guidelines for food provision for older adults in residential care (Food Standards Agency 2007) recommend levels five minerals (sodium, potassium, magnesium, iron and zinc) and three vitamins (riboflavin, vitamin D and folate). It should also be noted that the Department of Health recommended nutrient intake (RNI) values for minerals and vitamins give guidelines for the 50+ age group, but there are no such guidelines in place for an older age group. The most recent UK NDNS report from May 2014 (Public Health England 2014) summarises intake and deficiency of nutrients in adults over 65 years of age, but not in an institutionalised cohort. It concludes that in the over 65 age group mean intake of all vitamins met the RNI, except for vitamin D which only met $33 \%$ of the RNI. Regarding minerals, mean intakes of potassium, magnesium and selenium were below the RNI, although this was the case in all age groups. It was reported that mean intake of iron, calcium, vitamin $\mathrm{C}$ and folate were higher in the over 65 age group than reported in previous surveys. Although this is good news, there is no evidence to suggest that institutionalised older adults are meeting their RNI for these nutrients.

\subsection{Sauce Types}

Tomato based sauce, white sauce and gravy are three commonly used sauces in the UK (CookinInfo 2014), aside from the bottled sauces applied at the table (e.g. Ketchup). Tomato sauces are typically served on pasta or with meat or fish, with the tomatoes being an important source of carotenoids. White sauces are produced using fat, a thickener and milk. They are widely used in the UK within fish recipes and, to a lesser extent, within pasta. Gravy is typically applied to meat dishes as well as to vegetable and potato side dishes. Although traditionally produced using meat stock, meat fat and thickener, gravy is widely available as a commercial dried product containing stock, yeast extract and thickeners to which water is added before serving. Typically neither tomato sauce nor commercial 
“instant” gravy, would be particularly energy or protein dense, while white sauces are generally more energy and protein dense.

In view of the potential for sauces to increase nutrient provision in older hospital patients the aim of this study was to develop a range of savoury sauces fortified with energy, protein and micronutrients, delivering high taste impact and acceptable sensory profiles for older adults.

\section{Materials and methods}

\subsection{Materials for Tomato Sauce}

A tomato base was prepared using chopped tomatoes (Napolina Ltd., UK), extra virgin olive oil (Filippo Berio Ltd., UK), garlic granules and onion granules (McCormick UK Ltd.), salt basil, parsley, oregano and lemon juice (local retailer). Fortified formulations (Table 1) contained combinations of sunflower oil, double cream, unsalted butter (local retailer), double concentrated tomato puree (Napolina Ltd., UK), whey protein isolate (WPI) (protein content minimum 94\%, fat $0.2 \%$ ) (Volac International Ltd., UK), maltodextrin $\left(\mathrm{C}^{*}\right.$ dry, Cargill PLC, UK), and a de-oiled soybean lecithin (Emulpur IP, Cargill PLC, UK). Tomato puree was used to restore the red colour where ingredients resulted in a pale coloured sauce. The lecithin prevented separation of the sauces when extra lipid was added.

\subsection{Materials for White Sauce:}

White sauce (Table 2) was prepared using semi-skimmed (1.7\% fat) or whole pasteurised milk ( $4 \%$ fat), salted butter, white flour, salt, nutmeg, white pepper and bay leaves (local retailer). Mineral water was used to compensate for the losses during cooking (Harrogate Spring Water Ltd., UK). Double cream (local retailer) or WPI (as above, Volac, UK) were added to increase energy and protein content.

\subsection{Materials for Gravy:}


150 Gravy (Table 3) was produced using commercial gravy granules (Bisto, or Bisto reduced salt 151 gravy granules, Premier Foods, UK) and water (Harrogate Spring Water Ltd., UK).

152 Fortification utilised unsalted butter or double cream (local retailer) soy sauce (Pearl River, 153 sodium content 5.8g per 100ml, Guangdong PRB Bio-tech co, Ltd., China), Kikkoman low 154 salt soy sauce (sodium 3.6g per 100ml, Kikkoman Foods Europe B.V., Netherlands) and deoiled soybean lecithin (Emulpur IP, Cargill PLC, UK).

Taste enhancement was achieved through the use of soy sauce and a commercial flavour enhancer (sodium 3g/100g, glutamate 16g/100g; Givaudan Schweiz AG, Switzerland).

\subsection{Micronutrient addition to Sauce:}

A micronutrient blend (Lycored, Kent, UK) (an orange-yellow coloured powder) was used at $0.1 \%(\mathrm{w} / \mathrm{w})$. The premix $(100 \mathrm{mg})$ contained iron $(6 \mathrm{mg})$, zinc $(6.4 \mathrm{mg})$, riboflavin $(0.8 \mathrm{mg})$, vitamin B6 (0.86 mg), folic acid (134 $\mu \mathrm{g})$, vitamin C (26.6 mg) and vitamin D (6.6 $\mu \mathrm{g})$. In addition, the sauces were enriched with potassium and magnesium. Initially dipotassium hydrogen phosphate $\left(\mathrm{K}_{2} \mathrm{HPO}_{4}\right)(45 \% \mathrm{~K}$ by weight $)(5.16 \%(\mathrm{w} / \mathrm{w})$ addition), and magnesium oxide $(\mathrm{MgO})(60 \% \mathrm{Mg}$ by weight) $(0.34 \%$ (w/w) addition) were used to provide one-third of the RNI of potassium and magnesium in $50 \mathrm{~g}$ of sauce. However, due to excessive bitter and metallic taste these concentrations were lowered to $1.2 \%$ and $0.08 \%(\mathrm{w} / \mathrm{w})$ for $\mathrm{K}_{2} \mathrm{HPO}_{4}$ and $\mathrm{MgO}$ respectively following tasting trials. These percentages corresponded to $18.4 \%$ and $14.2 \%$ of RNI for potassium and magnesium respectively in a portion of sauce $(50 \mathrm{~g})$. The potassium salt was later replaced with $1.5 \%(\mathrm{ww})$ tri-potassium citrate monohydrate $\left(\mathrm{C}_{6} \mathrm{H}_{5} \mathrm{~K}_{3} \mathrm{O}_{7} . \mathrm{H}_{2} \mathrm{O}\right)(36 \% \mathrm{~K}$ by weight) aiming to improve taste acceptability.

\subsection{Tomato Sauce preparation}

Chopped tomatoes were blended (laboratory microniser), all other ingredients were added and the sauce blend was cooked (20 min, low heat, stirred at $10 \mathrm{~min}$ ). 
Butter and bay leaves were heated (low heat) until butter melted. White flour added, stirred and heated (2 min). Milk added gradually, continuous stirred until the sauce reached boiling point (ca. $10 \mathrm{~min}$ ). Other ingredients (double cream, WPI, micronutrients) then added, heated

178 for a further 2 minutes, stirring occasionally. Sauce seasoned with salt, white pepper and nutmeg. Bay leaves removed and the sauce was re-diluted with water to account for $15 \%$ weight loss due to evaporation.

\subsection{Gravy preparation}

Boiling water was added to the commercial gravy granules, all additional ingredients were added, continuously stirring until dissolved and blended (electric hand blender, $1 \mathrm{~min}$ ).

\subsection{Nutritional Profile}

Calculations were made in order to define the nutritional profile of sauces using the software Dietplan 6 (Forestfield Software Ltd., Horsham, UK).

\subsection{Sensory profile analysis}

All samples were frozen post manufacture $\left(-18^{\circ} \mathrm{C}\right)$. For sensory analysis, samples were defrosted at ambient temperature for 2 hours, heated in a microwave ( $5 \mathrm{~min}$, stirred at 2.5 $\min$ ) to a temperature of $75^{\circ} \mathrm{C}$, and held in a heated trolley for up to $20 \mathrm{~min}$. Sensory profiling of sauces was conducted by a trained panel ( $n=8$ to 11 ; average age 48 years). The panel developed a consensus vocabulary for all samples. Attribute scoring was on 140 mm unstructured line-scales (scaled 0-100) using Compusense ${ }^{\circledR}$ software (Version 5.0, Canada). Panellists were seated in individual testing booths under artificial daylight, except for white sauce samples which were evaluated under red light. Samples were presented in a balanced order, coded with random 3 digit numbers. Scoring was carried out in duplicate on separate days. 
Macronutrient fortified samples were initially compared to control tomato sauce (Table 1).

The cream and WPI plus maltodextrin fortified sauces were further fortified with

201 micronutrients and profiled.

\subsubsection{Sensory profiling of fortified white sauces}

203 Four samples were evaluated: Control, Energy Fortified, Energy, Protein and Micronutrient

204 fortified and maximum nutrient fortified (Table 2).

\subsubsection{Sensory profiling of fortified gravies}

Macronutrient fortified gravy was initially compared to control gravy (Table 3). Energy enhancers were used (vegetable oil, butter, double cream) with soy sauce (Pearl River Bridge) to darken the colour. The macronutrient fortified gravy was then compared to options further fortified with micronutrients and / or flavour enhancement.

\subsection{Hedonic liking evaluation}

211 The part of the study to test the hedonic liking was given a favourable ethical opinion for

212 conduct by the University of Reading Research Ethics Committee (study number 0830).

213 Healthy older volunteers ( $n==31$ for tomato sauce; $n=36$ for gravy), age 62-87 years (mean

214 age 71 years), rated their liking for tomato sauce and gravy samples on a hedonic category scale ranging from 1 (dislike extremely) to 9 (like extremely). The consumer tests were carried out in a central location where the tables were laid out to form a restaurant-like environment. All samples were presented monadically in a balanced order and labelled with 3 digit random codes.

219 The tomato sauce samples initially rated were the control and the three macronutrient fortified samples (Table 1). Samples $(30 \mathrm{~g})$ were served at $75 \pm 5{ }^{\circ} \mathrm{C}$ in paper cups $(100 \mathrm{ml})$. In a separate assessment, the control tomato sauce was compared to the double cream plus 
micronutrient fortified sample, where sauce $(40+/-5 \mathrm{~g})$ and pasta $(40+/-5 \mathrm{~g})$ were served in paper cups (100ml) with a plastic fork.

224 Two gravies were rated, the control and the macronutrient fortified option (table 3). Samples (20g) were served at $75 \pm 5^{\circ} \mathrm{C}$, poured over mashed potato $(30 \mathrm{~g})$ in transparent plastic dishes (200ml). Hedonic testing of the white sauces was not carried out (see discussion section 3.3).

\subsection{Data analysis:}

Statistical analysis of sensory profiling data was performed using two-way analysis of variance, with main effects tested against the sample by assessor interaction, and Fisher's LSD test for multiple comparisons, using Senpaq (SenPaq, v4.2; Qi Statistics Ltd; Reading, UK). The 9-point hedonic liking data was analysed using the Wilcoxon Signed Rank Test using XLStat (XLStat version 2009, Addinsoft, France).

\section{Results and Discussion}

\subsection{Nutritional Information}

\subsubsection{Tomato sauce}

237 The nutritional profile of the tomato sauces is shown in Table 5. The energy content of the fortified formulations was increased 3 to 4 fold compared with the control, predominantly through the use of high lipid ingredients; butter, vegetable oils and/or cream (Table 1). Protein and carbohydrate levels were increased 1.9 and 1.5 fold respectively when WPI and maltodextrin were used. Table 4 compares the double cream plus micronutrients sauce variant (the variant selected for hedonic testing, section 3.2 ) to the dietary reference values (DRV) for macronutrients and reference nutrient intake (RNI) values for micronutrient, for older people (Department of Health 1991). Assuming a 50 g portion size of sauce, the maximum energy and protein provided was rather limited, $4 \%$ and $2 \%$ of the DRV 
respectively. However it is expected from previous authors (Appleton, 2009) that the use of sauce would not only provide macronutrients itself, but also lead to a greater intake of nutrients from the meal to which it was applied. A portion size of $50 \mathrm{~g}$ is conservative, if used as a pasta sauce for example the portion size could be 2 to 4 fold higher, providing up to $16 \%$ and $8 \%$ of DRV for energy and protein respectively. Micronutrient addition enriched the sauces with vitamins and minerals. However, the ingredients used to achieve the macronutrient fortification also contributed to the micronutrient content of the sauce; all fortified sauces were higher in potassium and vitamin E, and to a lesser extent thiamine, riboflavin, niacin, pantothenic acid and biotin. The sauce fortified with double cream was higher in copper, iodine, retinol and vitamin D. The sauce fortified with WPI was higher in

\subsubsection{White sauce}

The energy content of fortified white sauces (Table 6) was 2.5 fold higher than the control, primarily due to whole milk and double cream (Table 2), which also increased the fat content more than three fold. Although WPI was used to increase the protein content, the overall increase was small, from 3.8 to $4.5 \%$ (w/w). Whole milk and double cream increased the levels of retinol, carotene and vitamin E delivered, as they are fat soluble vitamins. The major contribution to micronutrients was through the addition of the vitamin and mineral premix (Table 6). It was noted however, that the macronutrient fortification led to a decrease in calcium delivered compared with the control, this was not intentional and could be rectified through the mineral premix addition in future developments. A $50 \mathrm{~g}$ portion of the maximum nutrient fortified would provide $35 \%$ to $43 \%$ of the vitamins (D, riboflavin, $\mathrm{B}_{6}$, folate and C), iron and zinc as well as $10 \%$ of both potassium and magnesium RNI for older 
people (DH 1991) (Table 4), however it should be noted that this sauce did not have an optimised sensory profile (section 3.3) and required further development. The $50 \mathrm{~g}$ of portion of sauce would provide a limited amount of energy and protein, $6 \%$ and $4 \%$ of the DRV respectively. It was noted that as a dairy sauce it is relatively high in fat and provides $30 \%$ of the DRV for saturated fats. However, it is also noted that the sauces were developed primarily for provision to undernourished older hospital patients where increasing energy intake is paramount. DRVs were predominantly used as a guide for the micronutrient fortification.

\subsubsection{Gravy}

280 The nutrient profile of the fortified gravies (Table 7) showed a 2.8 fold energy increase compared with the control, achieved predominantly through the increase in fat (over 5 fold), through the addition of cream, oil and butter (Table 3). The maximum fortification that was practically possible did not have a significant impact on overall protein level. The micronutrient content of the gravies changed substantially after the incorporation of the vitamin and mineral premix (Table 8). The maximum fortified gravy (the final variant tested, Table 3) was compared to daily recommendations based on the FSA (2007) guidelines for nutrients for food provided to older people in residential care in Table 4. A $50 \mathrm{~g}$ portion of this gravy would provide $33 \%$ to $34 \%$ of the vitamins (D, riboflavin, $\mathrm{B}_{6}$, folate and $\mathrm{C}$ ) iron and zinc as well as $8 \%$ of both potassium and magnesium RNI for older people in residential care (Food Standards Agency 2007). The 50g of portion of sauce would provide only $3 \%$ energy and $1 \%$ protein of the DRV.

Across all three sauce types the macronutrient enhancement was partly achieved through the addition of high fat ingredients. The UK FSA recommendations (Food StandardsAgency 2007) for food provision to older adults in long term residential care recommend restricting fat intake to a maximum of $76 \mathrm{~g}$ per day, with a maximum of $24 \mathrm{~g}$ saturated fat per day. So, 
certainly in long term care and in the community, routinely increasing fat content should not

297 be recommended without taking into account the persons baseline nutritional and medical status. However, within acute hospital care setting that the sauces were designed for, the energy intake of older patients is of primary importance as opposed to fat intake restriction.

\subsection{Sensory and hedonic evaluation of tomato sauces}

301 Between the four tomato sauce samples initially tested (control and three macronutrient fortified samples) there were significant differences between 25 of the 32 consensus attributes (data not shown). In appearance and mouthfeel the control was thicker, darker, lumpier, grainier, more gelatinous and fuller bodied than the macronutrient fortified samples, due to its increased content of chopped tomato. Unsurprisingly, samples which had the oiliest appearance and mouthfeel were the ones which contained both oil and either butter or cream.

The sample containing WPI and maltodextrin was not oilier than the control, despite oil addition. In terms of orthonasal smell and retronasal flavour, the control was less creamy and buttery; more herby and pungent, but had a significantly weaker tomato smell (mean values 29 compared to $38-44, \mathrm{p}=0.006$ ), implying successful utilisation of tomato puree in place of chopped tomatoes in the fortified sauces. With regard to taste, the control was less sweet, more bitter and sour than the macronutrient fortified products. It was also significantly more salty than the WPI plus maltodextrin and the butter products. The control had the most astringent and burning after effect. When the four tomato sauce samples were presented to older volunteers, significant differences in mean hedonic liking were found $(p<0.0001)$. Two

316 of the macronutrient fortified options, those containing double cream and WPI plus maltodextrin, were liked more than the control (mean liking scores of 5.9 and 5.7 compared to 4.5). The sample containing butter was not significantly different in liking score (mean 4.9) from the control. 
320 The two preferred macronutrient options were progressed to micronutrient fortification. It was important to study the effect of mineral addition to sauce containing WPI to examine possible textural issues (coagulation, flocculation, viscous appearance) or taste issues (bitter, metallic). The resulting four samples were directly compared through sensory profiling. There were significant differences in 18 of the 46 consensus attributes (Table 8). The nutrient premix had a yellowish-orange colour due to the iron inclusion. The iron undergoes oxidation when in contact with air, forming iron (III) oxide which has a red-brown colour, explaining the darker colour of the sauce.

The addition of micronutrients appeared to reduce the viscosity and lumpy texture of the samples; although this was only significant in the cream variant. This may be attributed to the stabilising action of the citrate salt on dairy ingredients. It has been shown that the addition of chelating agents, such as tri potassium citrate, in optimum concentration, can improve heat stability and texture in dairy systems by reducing the concentrations of ionic calcium (Mekmene and Gaucheron 2011). In terms of orthonasal smell and retronasal flavour the addition of micronutrients tended to lower sweet smell and, in the case of the cream sample, tomato smell, whereas meaty, fried onion and smoky flavours were enhanced. Of greater concern, the addition of micronutrients led to significantly higher bitter taste, which was more substantial in the WPI plus maltodextrin sample. Potassium and magnesium are known to have bitter taste at relatively low taste thresholds of $340-680 \mathrm{mg}$ and $100 \mathrm{mg}$ per litre respectively in pure solutions

340 (Lawless and others 2003; Schiffman and others 1995), and they were present in the micronutrient enhanced formulation at 8840 and $730 \mathrm{mg}$ per litre respectively. Bitter taste and meaty flavour remained higher in the micronutrient fortified samples as aftertaste effects. With regards to mouthfeel, micronutrient addition tended to reduce grainy mouthfeel and the WPI plus maltodextrin variants were grainier than the cream ones. This may be due to the 
powder form of both WPI and maltodextrin compared to the liquid form of double cream.

346 Oily and gelatinous mouthfeel were highest in the micronutrient enhanced cream sample.

347 As the cream variant with micronutrients tended to be less bitter, starchy and grainy that the

348 WPI option, it was progressed to consumer testing. Two tomato sauce samples (control and

349 double cream + micronutrients) were presented to older volunteers $(n=31)$, however, the

350 differences in mean hedonic liking did not reach significance $(\mathrm{p}=0.096)$. The control sample

351 received a lower mean liking score (5.3) than the fortified product (6.0). The potentially

352 negative attributes associated with micronutrient fortification, and detected by the sensory

353 panel do not, therefore, appear to have reduced liking by the older consumers.

\subsection{Sensory evaluation of white sauces}

The four white sauce variants were described by 38 consensus attributes, of which 29 were significantly different between samples (Table 9). Although the micronutrient enhanced white sauces had a more yellow colour, this difference was not rated; red lights were used to avoid biasing panel scores of other attributes. Concerning appearance and mouthfeel, the control white sauce was significantly thicker, lumpier, more glutinous, more mouthcoating and less smooth than the modified formulations. This was attributed to the higher amount of flour used in the control. All sauces were frozen post manufacture, thawed and reheated for sensory profiling. Although the native starch in flour is cooked during sauce preparation, any remaining native starches would be extensively damaged after a freeze/thaw cycle (Arocas and others 2009). In future, a combination of native starches and hydrocolloids could be used to improve stability. In the present study the sauce was more stable with higher fat (cream and whole milk) and less flour.

367 Concerning orthonasal smell and retronasal flavour, the main significant differences were caused by the addition of micronutrients which led to higher ratings of fish, metallic and chemical aroma. The fish aroma was very high in the maximum fortified sample and was 
attributed to the addition of K-citrate. Fishy aromas are typically caused by lipid oxidation and it is likely that this was catalysed by potassium. The chemical aroma occurred in both of the micronutrient fortified samples, hence is likely to be attributed to the inclusion of the vitamin and mineral premix and / or the magnesium oxide. Concerning taste, the maximum nutrient fortified sample was less sweet, and more salty, sour and bitter. The salty taste was attributed to micronutrient addition and not due to sodium which was virtually constant between samples (117-123mg Na/100g of sauce). Similarly, the minor difference in total sugars content (Table 6) does not explain the differences in sweetness, implying the tastes associated with the use of K-citrate (bitter, sour and salty) suppressed sample sweetness. Milk flavour was also lower where $\mathrm{K}$-citrate, $\mathrm{MgO}$ and the vitamin/mineral premix were added. Creamy flavour was, as expected, higher following the addition of cream in the macronutrient fortified options, but suppressed where K-citrate was added. The control sample had a more starchy flavour, explained by the slightly higher level of added flour. Nutmeg and pepper flavour were suppressed by both the macro- and micro-nutrient fortification. The maximum fortified sample was most mouthdrying. This might be explained by the high levels of potassium salt, by the higher levels of protein (4.5\%) in this sample, or a combination of the two factors. Previous studies have shown whey proteins to cause mouthdrying (Ye and others 2012). The control sauce led to the most burning after effect, perhaps attributed to its lower concentration of fat $(5.8 \%)$. Results of previous research indicated that increased fat content, up to approximately $20 \%$, increases lubrication and decreases sensations of roughness and dryness in semi-solid foods (Wijk and Prinz 2005).

Summarising the results, macronutrient fortification led to a smoother sauce with, not surprisingly, a creamier flavour. Addition of micronutrients (vitamin and mineral premix plus $\mathrm{MgO}$ ) did not substantially change the sauce attributes. However the addition of K-citrate at (1.6\%; 698mg K per $100 \mathrm{~g}$ sauce) led to fish and chemical off-flavours. Hedonic liking on the 
white sauce formulations was not carried out as the micronutrient fortification remained suboptimal.

Of 38 sensory attributes used to describe the profile of the control and macronutrient enhanced gravies, only 7 were significantly different between samples (data not shown). The macronutrient enhanced options was equally as brown as the control, through the use of soy sauce (Pearl River); whereas initial samples developed were too pale once ingredients such as cream, butter and oil were added. Although this particular soy sauce was high in sodium, the macronutrient fortified gravy used reduced salt gravy granules to equalise the salt content of the two samples. The fortified option was thinner and less oily than the control in appearance, with a richer mouthfeel. It was less savoury and starchy in smell, with more buttery and dairy flavour.

Hedonic liking of the control gravy and the macronutrient fortified gravy found no significant difference $(\mathrm{p}=0.57)$ with mean liking scores of 6.5 and 6.3 respectively.

The macronutrient fortified gravy was further modified by flavour enhancement (using a low salt soy sauce, rich in glutamate, plus a commercial flavour enhancer) and micronutrient

411 fortification. The presence of micronutrients caused several changes to the sensory profile of

412 the gravies (Table 10). Of 42 consensus attributes, 24 were significantly different between samples. The addition of micronutrients led to a lower brown appearance. When the commercial flavour enhancer was used, the addition of micronutrients suppressed aroma attributes such as savoury, onion, beef stock, red wine and acidic. Considering taste, bitterness was significantly higher with the incorporation of the flavour enhancer, but the

417 differences were not substantial. Concerning flavour, the addition of micronutrients led to suppression of beef and red wine flavour, but caused mushroom and nutty flavours. The 
addition of the powdered micronutrient premix caused a less smooth mouthfeel. Where the flavour enhancer was present, addition of micronutrients caused a less rich mouthfeel. In terms of after effects, both gravy types had stronger mushroom flavour after-effect where micronutrients were added. Overall the use of flavour enhancer significantly led to higher ratings of umami (savoury) taste and beef flavour, which might benefit the acceptability by older adults (Dermiki and others 2013). The incorporation of micronutrients only led to higher levels of potentially negative attributes (eg bitter), but to a relatively small extent.

\subsection{Limitations in the fortification of Whey Protein and Micronutrients}

The addition of WPI and the combination of WPI and micronutrients can lead to sauce instability. The macronutrient enhanced sauces developed in this study can be characterised as oil-in-water emulsions after the incorporation of high fat ingredients. Many food emulsions consist of droplets of fat or oil suspended in an aqueous medium. The interface between the oil and the water at the droplet surface must be occupied by surfactant molecules to prevent immediate aggregation or coalescence. Surfactants can be either small amphiphilic molecules (such as lecithin used in this study), and large surface active molecules, such as proteins (Biesalski and others 2003). Aggregation occurs where the surfactant layer cannot prevent the droplets from approaching one another. The net charge of a protein, and hence an adsorbed protein layer, is highly dependent on $\mathrm{pH}$. If the $\mathrm{pH}$ is close to the isoelectric point of the protein, its net charge approaches zero, which favours aggregation. Emulsions containing whey proteins are generally unstable at $\mathrm{pH}$ values close to 5, especially if the emulsion is heated (Biesalski and others 2003). The presence of calcium ions is inversely related to the $\mathrm{pH}$ (Geerts and others 1983) and therefore affects the stability of the emulsions. This is explained by binding of the calcium ions to the phosphoserine residues of the caseins, which reduces the negative charge on the protein, and so reduces stability. In our case, emulsion instability occurred in all three types of sauce when a certain concentration of whey protein 
444 isolate was exceeded. The addition of micronutrients in combination with WPI resulted in

445 coagulation of the sauces and this phenomenon was observed during the freezing/thawing

446 procedure. It has been reported that the casein micelles of milk are destabilised by slow

447 freezing (cryodestabilisation) and storage at a temperature in the range -10 to $-20^{\circ} \mathrm{C}$. This

448 causes a decrease in $\mathrm{pH}$ and an increase in the calcium ion concentration in the unfrozen

449 phase of milk (Fox and Brodkorb 2008). The most unstable sauce was the white sauce and

450 this might be due to its high concentration of milk constituents and their sensitivity to the

451 presence of minerals. The samples that were unstable were unacceptable for sensory

452 evaluation, therefore were not assessed. The maximum limit of WPI addition in each type of

453 sauce was established in the presence of other energy fortifying ingredients. Above this

454 maximum level, not only the texture and consistency of the sauce were affected but several

455 sensory properties as well such as smell, flavour and after effects.

456

\section{4. Conclusion}

This study demonstrated that a substantial increase in the energy and macronutrient content could be achieved in conventional sauces. This increase was implemented by the addition of ingredients such as double cream (all sauces), butter (tomato sauce and gravy), vegetable oil (tomato sauce and gravy), maltodextrin (tomato sauce), whole milk (white sauce), soy sauce (gravy) and WPI (tomato and white sauces), which are rich in macronutrients such as fat, carbohydrates and protein. This macronutrient fortification is considered suitable for the needs of many older adults at risk of malnutrition in an acute care setting. However, it is recognised that further development of such fortified sauces is needed to meet the needs of older adults with chronic conditions such as renal or cardio-vascular disease. 
Micronutrient fortification appropriate to the needs of older adults was achieved in tomato sauce and gravy through the use of vitamin and mineral premixes, however the micronutrient fortification of the white sauce required further optimisation.

For all micronutrient enhanced sauces, matching 1/3 of RNI could not be achieved for potassium and magnesium (Table 4) due to unacceptability taste, flavour and after effects.

Therefore, the concentration of these minerals had to be adjusted to a desired level in terms of acceptable sensory properties, in order to mimimise bitter and metallic taste and after effects and to avoid any texture and instability problems. For the micronutrient fortified tomato sauce, the addition of $33-40 \%$ of RNI for some vitamins (riboflavin, $\mathrm{B}_{6}$, folate and $\mathrm{C}$ ), $\mathrm{Fe}$ and $\mathrm{Zn}$, plus $10-13 \%$ of RNI for $\mathrm{K}$ and $\mathrm{Mg}$ in a $50 \mathrm{~g}$ sauce portion (Table 4), resulted in a sauce that was higher in meaty flavour and more bitter. However, this did not reduce the liking of the sauce as rated by older volunteers. For the micronutrient fortified white sauce, the addition of $35-43 \%$ of RNI for vitamins, Fe and $\mathrm{Zn}$, plus $10 \%$ of RNI for $\mathrm{K}$ and $\mathrm{Mg}$ in a $50 \mathrm{~g}$ sauce portion (Table 4), resulted in a sauce that was higher in fishy and chemical flavour as well as more bitter and metallic. However, when the K-citrate was excluded the fishy flavour and metallic taste were significantly lower. For the micronutrient fortified gravy, the addition of 33-34\% of RNI for some vitamins, Fe and Zn, plus $8 \%$ of RNI for $\mathrm{K}$ and $\mathrm{Mg}$ in a $50 \mathrm{~g}$ gravy portion (Table 4), resulted in a sauce that was higher in mushroom and nutty flavour. Further studies of the hedonic liking of the fortified sauces with the target community of older hospital patients should be carried out, and in particular the sauces needed to be tested within real meals. It is recommended that this is done with the fortified options of sauces developed in this study, but also with an option excluding potassium. Potassium was found to contribute substantially to negative flavour and taste, cause issues of sauce instability, and is not recommended for older patients with renal disease (Sinha and Agarwal 2013). 
491 Older patients with a diminished sense of taste and flavour perception could benefit from

492 flavour enhancement of the sauces. In this study, flavour enhancement of the nutrient

493 fortified gravy was carried out successfully using a commercial natural flavour enhancer as

494 well as yeast extracts. Further development needs to include optimisation of flavour

495 enhancers.

496 Finally, evaluating the effects of nutrient enhanced sauces on satiety post meal and appetite at 497 next meal, as well evaluating of the effects on overall food and nutrient consumption is 498 essential.

499 It is proposed that the development of fortified sauces is a simple approach to improving 500 energy intake for hospitalised older people, both through the nutrient composition of the sauce itself and due to the benefits of increasing sensorial taste and lubrication in the mouth.

\section{Acknowledgements:}

This work has been supported by the New Dynamics of Ageing programme, a joint research council initiative via the ESRC as part of MAPPMAL (a Multidisciplinary Approach to develop a Prototype for the Prevention of MALnutrition in older people: products, people, places and procedures). We are grateful to sensory panelists and healthy older consumers for their contributions to this study, and to Lycored for the supply or micronutrients and, in particular, to the technical guidance provided by David Berry at Lycored.

Author Contributions:

512 LM, YM, PM, OK and MG designed the research; RT, JW, VC and VA conducted the research; RT and LM analysed the data; RT and LM wrote the manuscript; RT, LM, PM and OK had primary responsibility for the final content. 
References

Appleton KM. 2009. Increases in energy, protein and fat intake following the addition of sauce to an older person's meal. Appetite 52:161-5.

Arocas A, Sanz T, Fiszman SM. 2009. Clean label starches as thickeners in white sauces. Shearing, heating and freeze/thaw stability. Food Hydrocolloids 23(8):2031-7.

BAPEN 2011. BAPEN's nutrition screening week 2011. Available from: http://www.bapen.org.uk/screening-for-malnutrition/nutrition-screening-week/nswreports/nsw11?showall=\&start=1. Accessed 2014 November 28.

Bates CJ, Prentice A, Cole, TJ, van der Pols JC, DoyleW, Finch S, Smithers G, Clarke PC. 1999. Micronutrients: highlights and research challenges from the 1994-5 National Diet and Nutrition Survey of people aged 65 years and over. Br J Nutr. 82(1):7-15.

Best RL, Appleton KM. 2011. Comparable increases in energy, protein and fat intakes following the addition of seasonings and sauces to an older person's meal. Appetite $56: 179-82$

Biesalski HK, Brummer RJ, Konig J, O'Connell MA, Ovesen L, Rechkemmer G, Stos K, Thurnham DI. 2003. Micronutrient deficiencies - Hohenheim Consensus Conference. Eur. J. Nutr. 42(6):353-63.

Cowan DT, Roberts J D, Fitzpatrick J M, While A E, Baldwin J. 2004. Nutritional status of older people in long term care settings: current status and future directions. International Journal of Nursing Studies 41:225-37.

Department of Health. 1991. Dietary Reference Values for Food Energy and Nutrients for the United Kingdom, HMSO.

Dermiki M, Mounayar R, Suwankanit C, Scott J, Kennedy OB, Mottram DS, Gosney MA, Blumenthal H, Methven L. 2013. Maximising umami taste in meat using natural 
ingredients: effects on chemistry, sensory perception and hedonic liking in young and old consumers. Journal of the Science of Food and Agriculture 93(13):3312-21.

English Sauces. 2014 Available from: http://www.cooksinfo.com/english-sauces. Accessed on 2015 January 28.

Food Standards Agency. 2007. Nutritional Guidelines for Food Served in Public Institutions: Food served to older people in residential care. Available from: http://collections.europarchive.org/tna/20100927130941/http://food.gov.uk/multimedi a/pdfs/olderresident.pdf. Accessed 2014 November 28.

Fox PF, Brodkorb A. 2008. The casein micelle: Historical aspects, current concepts and significance. International Dairy Journal 18(7):677-84.

Gall MJ, Grimble GK, Reeve NJ, Thomas SJ. 1998. Effect of providing fortified meals and between-meal snacks on energy and protein intake of hospital patients. Clin Nutr 17:259-64.

Geerts JP, Bekhof JJ, Scherjon JW. 1983. Determination of calcium-ion activities in milk with an ion-selective electrode-A linear relationship between the logarithm of time and the recovery of the calcium-ion activity after heat-treatment. Netherlands Milk and Dairy Journal 37(4):197-211.

Lawless HT, Rapacki F, Horne J, Hayes A. 2003. The taste of calcium and magnesium salts and anionic modifications. Food Quality and Preference 14:319 - 25.

Mekmene O, Gaucheron, F. 2011. Determination of calcium-binding constants of caseins, phosphoserine, citrate and pyrophosphate: A modelling approach using free calcium measurement. Food Chemistry 127(2):676-82.

Pennings B, Boirie Y, Senden JMG, Gijsen AP, Kuipers H, van Loon L. 2011. Whey protein stimulates postprandial muscle protein accretion more effectively than do casein and casein hydrolysate in older men. Am J Clin Nutr. 93(5):997-1005. 
565 Public Health England. 2014. National Diet and Nutrition Survey. Results from Years 1, 2, 3 and 4 (combined) of the Rolling Programme (2008/2009 - 2011/2012). In: Bates B, Lennox A, Prentice. A. B, C., Page P, Nicholson S, Swan G, editors. London.

Schiffman SS, Manning MP, Warwick ZS, Crumbliss AL. 1995. Detection of thresholds of human buccal cells on the perception of astringency in whey protein beverages. Physiol. Behav. 106(5):645-50.

578 


\begin{tabular}{|c|c|c|c|c|}
\hline & $\begin{array}{l}\text { Control } \\
\text { (g/kg) }\end{array}$ & $\begin{array}{l}\text { Butter } \\
\text { formulation } \\
(\mathrm{g} / \mathrm{kg})\end{array}$ & $\begin{array}{l}\begin{array}{l}\text { Double cream } \\
\text { formulation }^{\mathrm{a}}\end{array} \\
(\mathrm{g} / \mathrm{kg})\end{array}$ & 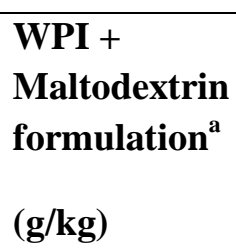 \\
\hline $\begin{array}{l}\text { Chopped } \\
\text { tomatoes }\end{array}$ & 723 & 581 & 515 & 524 \\
\hline Unsalted butter & - & 64 & - & - \\
\hline Olive oil & 16 & 13 & 12 & 12 \\
\hline Sunflower oil & - & 64 & 114 & 116 \\
\hline Tomato puree & - & 64 & 114 & 116 \\
\hline Double cream & - & - & 57 & - \\
\hline Maltodextrin & - & - & - & 29 \\
\hline $\begin{array}{l}\text { Whey Protein } \\
\text { Isolate (WPI) }\end{array}$ & - & - & - & 10 \\
\hline Onion granules & 43 & 35 & 31 & 31 \\
\hline Garlic granules & 16 & 13 & 12 & 12 \\
\hline Emulsifier & - & 3 & 3 & 3 \\
\hline Salt & 8 & 6 & 6 & 6 \\
\hline Basil (dried) & 2 & 2 & 1 & 1 \\
\hline Oregano (dried) & 2 & 2 & 1 & 1 \\
\hline Parsley (dried) & 2 & 2 & 1 & 1 \\
\hline Lemon juice & 8 & 8 & 6 & 6 \\
\hline Mineral water & 180 & 145 & 129 & 131 \\
\hline
\end{tabular}
mineral premix, $15 \mathrm{~g} / \mathrm{kg}$ tri-potassium citrate monohydrate and $0.8 \mathrm{~g} / \mathrm{kg}$ magnesium oxide. 


\begin{tabular}{|c|c|c|c|c|}
\hline & \multirow[b]{2}{*}{$\begin{array}{c}\text { Control } \\
(\mathrm{g} / \mathrm{kg})\end{array}$} & \multicolumn{3}{|c|}{ Energy, } \\
\hline & & $\begin{array}{c}\text { Energy } \\
\text { Fortified } \\
(\mathbf{g} / \mathbf{k g})\end{array}$ & $\begin{array}{c}\text { Protein and } \\
\text { micronutrient } \\
\text { fortified } \\
(\mathrm{g} / \mathrm{kg})\end{array}$ & $\begin{array}{c}\text { Maximum } \\
\text { Nutrient } \\
\text { Fortified (g/kg) }\end{array}$ \\
\hline $\begin{array}{l}\text { Semi-skimmed } \\
\text { pasteurised milk }\end{array}$ & 897 & - & - & - \\
\hline $\begin{array}{c}\text { Whole } \\
\text { pasteurised milk }\end{array}$ & - & 610 & 603 & 592 \\
\hline Salted butter & 51 & 41 & 40 & 40 \\
\hline Plain white flour & 50 & 41 & 40 & 40 \\
\hline Double cream & - & 305 & 301 & 296 \\
\hline WPI & - & - & 10 & 15 \\
\hline Salt & 1.0 & 1.0 & 1 & 1 \\
\hline Nutmeg & 0.1 & 0.1 & 0.1 & 0.1 \\
\hline White pepper & 0.4 & 0.4 & 0.4 & 0.4 \\
\hline Bay leaves & 0.4 & 0.4 & 0.4 & 0.4 \\
\hline $\begin{array}{c}\text { Vitamin and } \\
\text { mineral premix }\end{array}$ & - & - & 1 & 1 \\
\hline $\begin{array}{l}\text { Magnesium } \\
\text { oxide }\end{array}$ & - & - & 0.8 & 0.8 \\
\hline Tri-potassium & & & & \\
\hline $\begin{array}{c}\text { citrate } \\
\text { monohydrate }\end{array}$ & - & - & - & 15 \\
\hline
\end{tabular}




\begin{tabular}{|c|c|c|c|c|c|}
\hline & Control (g/kg) & $\begin{array}{l}\text { Macronutrient } \\
\text { fortified (g/kg) }\end{array}$ & $\begin{array}{c}\text { Macronutrient \& } \\
\text { Flavour } \\
\text { Enhancer }(\mathrm{g} / \mathrm{kg})\end{array}$ & $\begin{array}{c}\text { Macronutrient \& } \\
\text { Micronutrient } \\
\text { (g/kg) }\end{array}$ & $\begin{array}{c}\text { Macronutrient \& } \\
\text { Micronutrient \& } \\
\text { Flavour Enhancer } \\
(\mathrm{g} / \mathrm{kg})\end{array}$ \\
\hline Bisto gravy granules & 86.3 & 76.8 & 0 & 0 & 0 \\
\hline \multicolumn{6}{|l|}{ Bisto reduced salt } \\
\hline gravy granules & - & - & 73.6 & 75.7 & 72.6 \\
\hline Double cream & - & 34.7 & 33.2 & 34.1 & 32.7 \\
\hline Vegetable oil & - & 23.1 & 22.1 & 22.8 & 21.8 \\
\hline Unsalted butter & - & 46.2 & 44.3 & 45.5 & 43.7 \\
\hline Water & 909 & 809 & 775 & 797 & 764 \\
\hline \multicolumn{6}{|l|}{ Pearl River Bridge } \\
\hline Soy Sauce & - & 5.8 & 5.8 & 5.7 & 5.7 \\
\hline Lecithin & 5.1 & 5.0 & 4.9 & 5.0 & 4.8 \\
\hline \multicolumn{6}{|l|}{ Kikkoman low salt } \\
\hline soy sauce & - & - & 33.2 & - & 32.7 \\
\hline Flavour enhancer & - & - & 7.8 & - & 7.6 \\
\hline $\begin{array}{c}\text { Vitamin and mineral } \\
\text { premix } \\
\text { Dipotassium }\end{array}$ & - & - & - & 1 & 1 \\
\hline hydrogen phosphate & - & - & - & 12.8 & 12.6 \\
\hline Magnesium Oxide & - & - & - & 0.8 & 0.8 \\
\hline
\end{tabular}




\begin{tabular}{|c|c|c|c|c|c|c|c|}
\hline \multirow[b]{2}{*}{ Nutrient } & \multirow[b]{2}{*}{$\begin{array}{l}\text { Average Daily } \\
\text { Requirements }^{\text {a }}\end{array}$} & \multicolumn{3}{|c|}{ Nutrients per 50 g portion } & \multicolumn{3}{|c|}{ \% of Daily Requirement } \\
\hline & & $\begin{array}{l}\text { Tomato Sauce } \\
\text { : Double } \\
\text { cream plus } \\
\text { Micronutrient } \\
\text { s Formulation } \\
\end{array}$ & $\begin{array}{l}\text { White Sauce } \\
\text { : Maximum } \\
\text { Nutrient } \\
\text { Fortified } \\
\text { Formulation }\end{array}$ & $\begin{array}{c}\text { Gravy : Macro- } \\
\text { and Micro- } \\
\text { nutrient fortified } \\
\text { with flavour } \\
\text { enhancer }\end{array}$ & $\begin{array}{l}\text { Tomato Sauce : } \\
\text { Double cream plus } \\
\text { Micronutrients } \\
\text { Formulation }\end{array}$ & $\begin{array}{c}\text { White Sauce : } \\
\text { Maximum } \\
\text { Nutrient } \\
\text { Fortified } \\
\text { Formulation } \\
\end{array}$ & $\begin{array}{c}\text { Gravy : Macro- } \\
\text { and Mico- } \\
\text { nutrient fortified } \\
\text { with flavour } \\
\text { enhancer } \\
\end{array}$ \\
\hline $\begin{array}{l}\text { Vitamin D } \\
(\mu \mathrm{g})\end{array}$ & $>10 \mu \mathrm{g}$ & 3.3 & 3.5 & 3.3 & 33 & 35 & 33 \\
\hline $\begin{array}{l}\text { Riboflavin } \\
\left(\mathrm{B}_{2}\right)(\mathrm{mg})\end{array}$ & $>1.2 \mathrm{mg}$ & 0.42 & 0.52 & 0.40 & 35 & 43 & 33 \\
\hline $\begin{array}{c}\text { Vitamin } B_{6} \\
(\mathrm{mg})\end{array}$ & $\mathrm{nr}(>1.3 \mathrm{mg})^{\mathrm{b}}$ & 0.46 & 0.47 & 0.43 & 35 & 36 & 33 \\
\hline $\begin{array}{l}\text { Folate }\left(B_{9}\right) \\
\qquad(\mu \mathrm{g})\end{array}$ & $>200 \mu \mathrm{g}$ & 71 & 74 & 67 & 36 & 37 & 34 \\
\hline $\begin{array}{l}\text { Vitamin C } \\
\quad(\mathrm{mg})\end{array}$ & $\mathrm{nr}(>40 \mathrm{mg})^{\mathrm{b}}$ & 16 & 15 & 14 & 40 & 36 & 34 \\
\hline $\begin{array}{l}\text { Potassium } \\
\quad(\mathrm{mg})\end{array}$ & $>3500 \mathrm{mg}^{\mathrm{c}}$ & 440 & 349 & 293 & 13 & 10 & 8 \\
\hline $\begin{array}{l}\text { Magnesium } \\
\text { (mg) }\end{array}$ & $>300 \mathrm{mg}$ & 30 & 30 & 26 & 10 & 10 & 9 \\
\hline Iron (mg) & $>9 \mathrm{mg}$ & 3.3 & 3.2 & 3.0 & 37 & 36 & 34 \\
\hline Zinc (mg) & $>9.5 \mathrm{mg}$ & 3.3 & 3.5 & 3.2 & 35 & 37 & 34 \\
\hline $\begin{array}{l}\text { Energy } \\
\text { (kcal) }\end{array}$ & > $1955 \mathrm{kcal}$ & 87 & 123 & 54 & 4 & 6 & 3 \\
\hline Protein $(g)$ & $>50 \mathrm{~g}$ & 0.9 & 2.3 & 0.5 & 2 & 5 & 1 \\
\hline Fat $(\mathrm{g})$ & $<74.5 \mathrm{~g}$ & 8.0 & 11 & 4.5 & 11 & 15 & 6 \\
\hline $\operatorname{SFA}(\mathrm{g})$ & $<23.5 \mathrm{~g}$ & 1.8 & 7.2 & 2.3 & 17 & 30 & 10 \\
\hline
\end{tabular}

591 a Food Standards Agencey (2007) guidelines for nutrients for food provided to older people in residential care (Department of Health 1991 values)

$592 \mathrm{~b}$ nr = no recommendation specified; but highlighted as low intake and/or deficient in older adults (Bates and others, 1999, Russell \& Suter 1993)

593 cexcept in cases of renal disease where daily RNI $<274 \mathrm{mg}$ 


\begin{tabular}{|c|c|c|c|c|c|c|}
\hline & $\begin{array}{l}\text { Control } \\
(/ 100 g)\end{array}$ & $\begin{array}{l}\text { Butter } \\
\text { formulation } \\
(/ 100 g)\end{array}$ & $\begin{array}{l}\text { Double } \\
\text { cream } \\
\text { formulation } \\
(/ 100 g)\end{array}$ & $\begin{array}{l}\text { WPI } \\
\text { +Maltodextrin } \\
\text { formulation } \\
(/ 100 \mathrm{~g})\end{array}$ & $\begin{array}{l}\text { WPI + } \\
\text { Maltodextrin + } \\
\text { Micronutrients } \\
\text { Formulation } \\
(/ 100 g)\end{array}$ & $\begin{array}{l}\text { Double cream + } \\
\text { Micronutrients } \\
\text { formulation } \\
(/ 100 \mathrm{~g})\end{array}$ \\
\hline Energy (kcal) & 45 & 149 & 174 & 164 & 164 & 174 \\
\hline Protein $(\mathrm{g})$ & 1.5 & 1.6 & 1.8 & 2.8 & 2.8 & 1.8 \\
\hline Carbohydrates (g) & 5.6 & 5.4 & 5.6 & 8.4 & 8.4 & 5.6 \\
\hline \multicolumn{7}{|l|}{ Of which sugars } \\
\hline$(\mathrm{g})$ & 4 & 4.2 & 4.5 & 7.4 & 7.4 & 4.5 \\
\hline Fat $(\mathrm{g})$ & 1.8 & 13.4 & 15.9 & 13.1 & 13.1 & 15.9 \\
\hline \multicolumn{7}{|l|}{ Of which } \\
\hline saturated (g) & 0.3 & 4.5 & 3.5 & 1.6 & 1.6 & 3.5 \\
\hline Fibre (g) & 1.7 & 1.6 & 1.6 & 1.6 & 1.6 & 1.6 \\
\hline Sodium (g) & 0.4 & 0.3 & 0.3 & 0.3 & 0.3 & 0.3 \\
\hline Salt (g) & 0.9 & 0.7 & 0.7 & 0.7 & 0.7 & 0.7 \\
\hline \multicolumn{7}{|l|}{ Minerals } \\
\hline $\begin{array}{l}\text { Sodium (Na) } \\
(\mathrm{mg})\end{array}$ & \multicolumn{5}{|c|}{ Sodium (Na) } & 290 \\
\hline \multicolumn{7}{|l|}{ Potassium (K) } \\
\hline \multicolumn{7}{|l|}{ Calcium (Ca) } \\
\hline \multicolumn{7}{|l|}{ Magnesium (Mg) } \\
\hline \multicolumn{7}{|l|}{ Phosphorus (P) } \\
\hline Iron $(\mathrm{Fe})(\mathrm{mg})$ & 0.73 & 0.74 & 0.65 & 0.68 & $6.66^{\mathrm{a}}$ & $6.65^{\mathrm{a}}$ \\
\hline Copper $(\mathrm{Cu})(\mathrm{mg})$ & 0.08 & 0.1 & 0.39 & 0.18 & 0.17 & 0.38 \\
\hline Zinc (Zn) (mg) & 0.22 & 0.21 & 0.22 & 0.27 & $6.65^{\mathrm{a}}$ & $6.61^{\mathrm{a}}$ \\
\hline \multicolumn{7}{|l|}{ Chloride $(\mathrm{Cl})$} \\
\hline \multicolumn{7}{|l|}{ Manganese (Mn) } \\
\hline \multicolumn{7}{|l|}{ Selenium (Se) } \\
\hline (ug) & 0.5 & 0.4 & 0.5 & 0.4 & 0.4 & 0.5 \\
\hline Iodine (I) (ug) & 3.6 & 2.9 & 4.6 & 2.6 & 2.6 & 4.5 \\
\hline \multicolumn{7}{|l|}{ Vitamins } \\
\hline$\overline{\text { Retinol (ug) }}$ & - & - & 44 & - & - & 44 \\
\hline Carotene (ug) & 328 & 391 & 322 & 430 & 424 & 318 \\
\hline Vitamin D (ug) & - & - & 0.02 & - & $6.59^{\mathrm{a}}$ & $6.62^{\mathrm{a}}$ \\
\hline Vitamin E (mg) & 1.1 & 4.38 & 7.1 & 7.12 & 7 & 6.98 \\
\hline Thiamin (mg) & 0.03 & 0.05 & 0.05 & 0.07 & 0.07 & 0.05 \\
\hline Riboflavin (mg) & 0.01 & 0.02 & 0.04 & 0.03 & $0.82^{\mathrm{a}}$ & $0.83^{\mathrm{a}}$ \\
\hline Niacin (mg) & 0.43 & 0.61 & 0.62 & 0.77 & 0.75 & 0.61 \\
\hline Tryptophan (mg) & 0.252 & 0.251 & 0.277 & 0.262 & 0.26 & 0.268 \\
\hline Vitamin B6 (mg) & 0.06 & 0.06 & 0.05 & 0.06 & $0.92^{\mathrm{a}}$ & $0.91^{\mathrm{a}}$ \\
\hline Vitamin B12 (ug) & - & - & Trace & - & - & Trace \\
\hline Total Folate(ug) & 8 & 9 & 8 & 11 & $145^{\mathrm{a}}$ & $142^{\mathrm{a}}$ \\
\hline $\begin{array}{c}\text { Pantothenic acid, } \\
\text { Pantothenate } \\
\text { (mg) }\end{array}$ & 0.18 & 0.21 & 0.25 & 0.24 & 0.24 & 0.25 \\
\hline Biotin (ug) & 1.1 & 1.3 & 1.5 & 1.5 & 1.5 & 1.5 \\
\hline Vitamin C (mg) & 6 & 5 & 5 & 6 & $32^{\mathrm{a}}$ & $32^{\mathrm{a}}$ \\
\hline
\end{tabular}

${ }^{\mathrm{a}}$ Micronutrients added directly as a premix 


\begin{tabular}{|c|c|c|c|c|}
\hline & Control (/100g) & $\begin{array}{c}\text { Energy Fortified } \\
(/ 100 \mathrm{~g})\end{array}$ & $\begin{array}{c}\text { Energy, Protein } \\
\text { and micronutrient } \\
\text { fortified }(/ 100 g)\end{array}$ & $\begin{array}{l}\text { Maximum Nutrient } \\
\text { Fortified }(/ \mathbf{1 0 0 g})\end{array}$ \\
\hline Energy (kcal) & 98 & 248 & 249 & 246 \\
\hline Protein $(\mathrm{g})$ & 3.8 & 3.1 & 4 & 4.5 \\
\hline Carbohydrates (g) & 8.5 & 6.9 & 6.8 & 6.7 \\
\hline Of which sugars (g) & 4.6 & 3.6 & 3.6 & 3.5 \\
\hline Fat $(\mathrm{g})$ & 5.8 & 23.3 & 23 & 22.6 \\
\hline \multicolumn{5}{|l|}{ Of which saturated } \\
\hline$(\mathrm{g})$ & 3.9 & 14.8 & 14.6 & 14.3 \\
\hline Fibre $(\mathrm{g})$ & 0.2 & 0.2 & 0.2 & 0.2 \\
\hline Sodium (g) & 0.12 & 0.12 & 0.12 & 0.12 \\
\hline Salt (g) & 0.31 & 0.3 & 0.3 & 0.29 \\
\hline \multicolumn{5}{|l|}{ Minerals } \\
\hline Sodium (Na) (mg) & 123 & 118 & 119 & 117 \\
\hline Potassium (K) (mg) & 156 & 127 & 128 & $698^{\mathrm{a}}$ \\
\hline Calcium (Ca) (mg) & 122 & 98 & 102 & 102 \\
\hline \multicolumn{5}{|l|}{ Magnesium (Mg) } \\
\hline$(\mathrm{mg})$ & 12 & 10 & $58 \mathrm{a}$ & $59 a$ \\
\hline Phosphorus (P) (mg) & 95 & 81 & 83 & 82 \\
\hline Iron $(\mathrm{Fe})(\mathrm{mg})$ & 0.15 & 0.15 & $6.51 \mathrm{a}$ & $6.39 a$ \\
\hline Copper $(\mathrm{Cu})(\mathrm{mg})$ & 0.01 & 0.01 & 0.06 & 0.09 \\
\hline Zinc (Zn) (mg) & 0.41 & 0.35 & $7.17 \mathrm{a}$ & $7.05 \mathrm{a}$ \\
\hline Chloride $(\mathrm{Cl})(\mathrm{mg})$ & 150 & 147 & 146 & 143 \\
\hline \multicolumn{5}{|l|}{ Manganese (Mn) } \\
\hline$(\mathrm{mg})$ & 0.04 & 0.03 & 0.04 & 0.05 \\
\hline Selenium (Se) (ug) & 1.1 & 1.7 & 1.7 & 1.7 \\
\hline Iodine (I) (ug) & 29 & 31.7 & 31.3 & 30.7 \\
\hline \multicolumn{5}{|l|}{ Vitamins } \\
\hline Retinol (ug) & 18 & 270 & 267 & 261 \\
\hline Carotene (ug) & 10 & 169 & 167 & 164 \\
\hline Vitamin D (ug) & - & 0.1 & $7.09 \mathrm{a}$ & $6.94 a$ \\
\hline Vitamin E (mg) & 0.05 & 0.59 & 0.58 & 0.57 \\
\hline Thiamin (mg) & 0.04 & 0.04 & 0.04 & 0.04 \\
\hline Riboflavin (mg) & 0.23 & 0.21 & $1.05 \mathrm{a}$ & $1.03 \mathrm{a}$ \\
\hline Niacin (mg) & 0.18 & 0.2 & 0.2 & 0.2 \\
\hline Tryptophan (mg) & 0.667 & 0.565 & 0.558 & 0.547 \\
\hline Vitamin B6 (mg) & 0.06 & 0.05 & $0.96 \mathrm{a}$ & $0.94 \mathrm{a}$ \\
\hline Vitamin B12 (ug) & 0.9 & 0.8 & 0.8 & 0.7 \\
\hline Total Folate (ug) & 10 & 8 & $150 \mathrm{a}$ & $147 \mathrm{a}$ \\
\hline \multicolumn{5}{|l|}{ Pantothenic acid, } \\
\hline Pantothenate (mg) & 0.66 & 0.46 & 0.45 & 0.45 \\
\hline Biotin (ug) & 2.9 & 1.9 & 1.9 & 1.9 \\
\hline Vitamin C (mg) & 2 & 2 & $30 \mathrm{a}$ & $29 a$ \\
\hline
\end{tabular}




\begin{tabular}{|c|c|c|c|c|c|}
\hline & Control (/100g) & $\begin{array}{l}\text { Macronutrient } \\
\text { fortified (/100g) }\end{array}$ & $\begin{array}{c}\text { Macronutrient } \\
\text { \& Flavour } \\
\text { Enhancer } \\
(/ \mathbf{1 0 0 g})\end{array}$ & $\begin{array}{c}\text { Macronutrient } \\
\& \\
\text { Micronutrient } \\
(/ \mathbf{1 0 0 g})\end{array}$ & $\begin{array}{c}\text { Macronutrient } \\
\text { \& } \\
\text { Micronutrient } \\
\text { \& Flavour } \\
\text { Enhancer } \\
\text { (/100g) }\end{array}$ \\
\hline Energy (kcal) & 38 & 107 & 109 & 106 & 107 \\
\hline Protein $(\mathrm{g})$ & 0.2 & 0.3 & 0.9 & 0.3 & 0.9 \\
\hline Carbohydrates & & & & & \\
\hline$(\mathrm{g})$ & 5.6 & 5.2 & 5.6 & 5.1 & 5.5 \\
\hline Of which sugars & & & & & \\
\hline$(\mathrm{g})$ & 1.4 & 1.3 & 1.6 & 1.4 & 1.5 \\
\hline Fat $(\mathrm{g})$ & 1.7 & 9.5 & 9.1 & 9.3 & 8.9 \\
\hline Of which & & & & & \\
\hline saturated (g) & 1 & 4.8 & 4.6 & 4.8 & 4.6 \\
\hline Fibre (g) & - & - & Trace & - & Trace \\
\hline Sodium (g) & 0.48 & 0.46 & 0.49 & 0.35 & 0.48 \\
\hline Salt (g) & 1.2 & 1.16 & 1.23 & 0.86 & 1.2 \\
\hline$\underline{\text { Minerals }^{\mathbf{a}}}$ & & & & & \\
\hline $\begin{array}{l}\text { Sodium (Na) } \\
\text { (mg) }\end{array}$ & 482 & 462 & 490 & 347 & 482 \\
\hline Potassium (K) & & & & & \\
\hline $\begin{array}{c}(\mathrm{mg}) \\
\text { Calcium }(\mathrm{Ca})\end{array}$ & 19 & 20 & 19 & 594 & 585 \\
\hline$(\mathrm{mg})$ & 7 & 8 & 7 & 8 & 7 \\
\hline $\begin{array}{c}\text { Magnesium (Mg) } \\
\text { (mg) }\end{array}$ & 3 & 3 & 3 & 51 & 51 \\
\hline Phosphorus (P) & & & & & \\
\hline (mg) & 6 & 7 & 7 & 7 & 7 \\
\hline Iron $(\mathrm{Fe})(\mathrm{mg})$ & 0.06 & 0.06 & 0.06 & 0.02 & 6.06 \\
\hline Copper $(\mathrm{Cu})$ & & & & & \\
\hline (mg) & 0.02 & 0.02 & 0.02 & - & 0.02 \\
\hline Zinc (Zn) (mg) & 0.03 & 0.03 & 0.03 & 6.42 & 6.42 \\
\hline Manganese (Mn) & & & & & \\
\hline$(\mathrm{mg})$ & 0.03 & 0.03 & 0.03 & 0.03 & 0.03 \\
\hline Selenium (Se) & & & & & \\
\hline (ug) & - & 0.1 & 0.1 & 0.1 & 0.1 \\
\hline Iodine (I) (ug) & - & 1.5 & 1.4 & 1.4 & 1.4 \\
\hline$\underline{\text { Vitamins }}^{\mathrm{a}}$ & - & & & & \\
\hline$\overline{\text { Retinol (ug) }}$ & - & 27 & 26 & 27 & 25 \\
\hline Carotene (ug) & - & 17 & 16 & 16 & 16 \\
\hline Vitamin D (ug) & - & 0.01 & 0.01 & 6.61 & 6.61 \\
\hline Vitamin E (mg) & - & 0.06 & 0.05 & 0.06 & 0.05 \\
\hline Thiamin (mg) & - & Trace & Trace & Trace & Trace \\
\hline Riboflavin (mg) & - & 0.01 & 0.01 & 0.8 & 0.8 \\
\hline Niacin $(m g)$ & - & - & - & - & - \\
\hline Tryptophan (mg) & 0.07 & 0.07 & 0.07 & 0.07 & 0.07 \\
\hline Vitamin B6 (mg) & - & Trace & Trace & 0.86 & 0.86 \\
\hline Vitamin B12 (ug) & - & Trace & Trace & Trace & Trace \\
\hline Total Folate (ug) & - & Trace & Trace & 134 & 134 \\
\hline $\begin{array}{c}\text { Pantothenic acid, } \\
\text { Pantothenate }\end{array}$ & & & & & \\
\hline$(\mathrm{mg})$ & - & 0.01 & 0.01 & 0.01 & 0.01 \\
\hline Biotin (ug) & - & Trace & Trace & Trace & Trace \\
\hline Vitamin C (mg) & - & Trace & Trace & 27 & 27 \\
\hline
\end{tabular}

${ }^{\text {a }}$ Nutrient information for commercial gravy granules combined from pack declaration (macronutrient) and 605 McCance \&Widdowson food tables (micronutrient) 


\begin{tabular}{|c|c|c|c|c|c|}
\hline Modality & Arrtibute & $\begin{array}{c}\text { Double } \\
\text { cream }\end{array}$ & $\begin{array}{c}\text { Double cream } \\
+ \\
\text { Micronutrients } \\
\end{array}$ & $\begin{array}{c}\text { WPI + } \\
\text { Maltodextrin }\end{array}$ & $\begin{array}{c}\text { WPI + } \\
\text { Maltodextrin + } \\
\text { Micronutrients } \\
\end{array}$ \\
\hline \multirow{6}{*}{ Appearance } & Lightness of & & & & \\
\hline & $\begin{array}{l}\text { Brown } \\
\text { Colour }\end{array}$ & $59.8^{\mathrm{b}}$ & $69.5^{\mathrm{a}}$ & $54.8^{\mathrm{b}}$ & $56.1^{\mathrm{b}}$ \\
\hline & Thickness & $63.1^{\mathrm{a}}$ & $49.1^{\mathrm{b}}$ & $64.3^{\mathrm{a}}$ & $57^{\mathrm{ab}}$ \\
\hline & Lumpy & $28.7^{\mathrm{a}}$ & $21.7^{\mathrm{b}}$ & $31.6^{\mathrm{a}}$ & $27.5^{\mathrm{ab}}$ \\
\hline & Green bits* & $20.8^{\mathrm{b}}$ & $25.6^{\mathrm{ab}}$ & $28.8^{\mathrm{a}}$ & $23^{\mathrm{ab}}$ \\
\hline & Oily & $20.8^{b}$ & $31.2^{\mathrm{a}}$ & $23^{b}$ & $22.8^{\mathrm{b}}$ \\
\hline \multirow{2}{*}{ Odour } & Tomato & $57.1^{\mathrm{a}}$ & $45.8^{\mathrm{b}}$ & $50^{\mathrm{ab}}$ & $52.2^{\mathrm{ab}}$ \\
\hline & Sweet & $38.1^{\mathrm{a}}$ & $30.1^{b}$ & $37^{\mathrm{ab}}$ & $32.5^{\mathrm{ab}}$ \\
\hline \multirow[t]{2}{*}{ Taste } & Bitter & $27.2^{\mathrm{b}}$ & $37.5^{\mathrm{ab}}$ & $28.2^{\mathrm{b}}$ & $43.5^{\mathrm{a}}$ \\
\hline & Starchy & $20.1^{b}$ & $26.4^{\mathrm{ab}}$ & $24.1^{\mathrm{ab}}$ & $31.6^{\mathrm{a}}$ \\
\hline \multirow[t]{3}{*}{ Flavour } & $\begin{array}{c}\text { Meaty } \\
\text { (intense } \\
\text { seafood type) }\end{array}$ & $11.1^{\mathrm{b}}$ & $25^{\mathrm{a}}$ & $7.1^{\mathrm{b}}$ & $28.2^{\mathrm{a}}$ \\
\hline & Fried onions & $16.8^{\mathrm{b}}$ & $32.8^{\mathrm{a}}$ & $19.8^{b}$ & $24^{\mathrm{ab}}$ \\
\hline & Smoky & $10.2^{\mathrm{ab}}$ & $13.9^{\mathrm{ab}}$ & $8.4^{\mathrm{b}}$ & $16.6^{\mathrm{a}}$ \\
\hline \multirow{4}{*}{ Mouthfeel } & $\begin{array}{l}\text { Grainy } \\
\text { Oily }\end{array}$ & $29.6^{\mathrm{ab}}$ & $22^{\mathrm{b}}$ & $35.1^{\mathrm{a}}$ & $29.6^{\mathrm{ab}}$ \\
\hline & (mouthfeel) & $20.6^{\mathrm{c}}$ & $37.8^{\mathrm{a}}$ & $29.2^{b}$ & $29.6^{\mathrm{ab}}$ \\
\hline & Gelatinous & $4.5^{\mathrm{b}}$ & $13^{\mathrm{a}}$ & $7.2^{\mathrm{ab}}$ & $7.8^{\mathrm{ab}}$ \\
\hline & Pieces & $14.7^{\mathrm{b}}$ & $14^{\mathrm{b}}$ & $25.6^{\mathrm{a}}$ & $16.3^{\mathrm{b}}$ \\
\hline After effects & $\begin{array}{c}\text { Meaty } \\
\text { (intense } \\
\text { seafood type) } \\
\text { Bitter }\end{array}$ & $\begin{array}{l}9.8 b^{c} \\
20.6^{b}\end{array}$ & $\begin{array}{l}20.5^{\mathrm{a}} \\
35.6^{\mathrm{ab}}\end{array}$ & $\begin{array}{l}8.3^{\mathrm{c}} \\
21.1^{\mathrm{b}}\end{array}$ & $\begin{array}{c}19^{\mathrm{ab}} \\
37.5^{\mathrm{a}}\end{array}$ \\
\hline
\end{tabular}

607

${ }^{a b c}$ Mean values with the same letter within the same row are not significantly different at $\mathrm{p}<0.05$

*Green bits were due to herb addition, differences are expected to be due to minor batch to batch variation

Attributes were no significant differences were found between products were appearance: black bits, separated, watery; smell : herbs, onion, butter, chicken stock, cheesy, savoury, burnt; taste : salty, sour , sweet, umami, metallic; flavour : creamy, buttery, ripe tomato, cooked tomato, herbs, cheesy, burnt; mouthfeel : full body ; aftereffect : astringent (mouthdrying), burning, oily lips, mouth coating, metallic 


\begin{tabular}{|c|c|c|c|c|c|}
\hline & & Control & $\begin{array}{c}\text { Energy } \\
\text { Fortified }\end{array}$ & $\begin{array}{l}\text { Energy, Protein and } \\
\text { micronutrient fortified }\end{array}$ & $\begin{array}{c}\text { Maximum } \\
\text { Nutrient Fortified }\end{array}$ \\
\hline \multirow{3}{*}{ Appearance } & Thick & $79.6^{\mathrm{a}}$ & $39.1^{\mathrm{c}}$ & $54.5^{\mathrm{b}}$ & $40.2^{\mathrm{c}}$ \\
\hline & Lumpy & $61.2^{\mathrm{a}}$ & $17.7^{\mathrm{c}}$ & $23.0^{\mathrm{b}}$ & $19.2^{\mathrm{b}}$ \\
\hline & Whisked & $7.1^{\mathrm{b}}$ & $20.7^{\mathrm{a}}$ & $17.2^{\mathrm{a}}$ & $19.1^{\mathrm{a}}$ \\
\hline \multirow{5}{*}{ Smell } & Milk & $49.5^{\mathrm{a}}$ & $48.8^{\mathrm{ab}}$ & $45.5^{\mathrm{ab}}$ & $39.5^{\mathrm{b}}$ \\
\hline & Fish & $10.0^{\mathrm{b}}$ & $10.2^{\mathrm{b}}$ & $19.5^{\mathrm{b}}$ & $42.9^{\mathrm{a}}$ \\
\hline & $\begin{array}{l}\text { Vegetable } \\
\text { soup (dry } \\
\text { pack) }\end{array}$ & $5.8^{\mathrm{b}}$ & $6.9^{\mathrm{ab}}$ & $11.5^{\mathrm{a}}$ & $8.1^{\mathrm{ab}}$ \\
\hline & Chemical & $8.0^{\mathrm{bc}}$ & $5.1^{\mathrm{c}}$ & $14.8^{\mathrm{ab}}$ & $19.8^{\mathrm{a}}$ \\
\hline & Savoury & $26.4^{\mathrm{a}}$ & $17.3^{\mathrm{b}}$ & $26.1^{\mathrm{a}}$ & $27.5^{\mathrm{a}}$ \\
\hline \multirow{4}{*}{ Taste } & Salty & $12.8^{\mathrm{b}}$ & $9.6^{\mathrm{b}}$ & $10.9^{\mathrm{b}}$ & $20.4^{\mathrm{a}}$ \\
\hline & Sweet & $23.0^{\mathrm{a}}$ & $24.1^{\mathrm{a}}$ & $17.9^{\mathrm{ab}}$ & $12.1^{\mathrm{b}}$ \\
\hline & Sour & $10.5^{\mathrm{bc}}$ & $6.4^{\mathrm{c}}$ & $12.8^{\mathrm{ab}}$ & $17.6^{\mathrm{a}}$ \\
\hline & Bitter & $13.9^{\mathrm{ab}}$ & $9.9^{\mathrm{b}}$ & $14.8^{\mathrm{ab}}$ & $20.7^{\mathrm{a}}$ \\
\hline \multirow{8}{*}{ Flavour } & Milk & $53.2^{\mathrm{a}}$ & $48.8^{\mathrm{ab}}$ & $40.1^{\mathrm{bc}}$ & $33.8^{\mathrm{c}}$ \\
\hline & Cream & $26.4^{\mathrm{ab}}$ & $38.3^{\mathrm{a}}$ & $32.9^{\mathrm{a}}$ & $20.0^{\mathrm{b}}$ \\
\hline & Starchy & $38.3^{\mathrm{a}}$ & $18.4^{\mathrm{c}}$ & $29.2^{\mathrm{b}}$ & $31.1^{\mathrm{b}}$ \\
\hline & Nutmeg & $37.3^{\mathrm{a}}$ & $28.7^{\mathrm{ab}}$ & $21.9^{\mathrm{b}}$ & $19.5^{\mathrm{b}}$ \\
\hline & Pepper & $23.6^{\mathrm{a}}$ & $13.6^{\mathrm{b}}$ & $15.5^{\mathrm{b}}$ & $15.8^{\mathrm{b}}$ \\
\hline & Chemical & $7.5^{\mathrm{b}}$ & $6.3^{\mathrm{b}}$ & $10.6^{\mathrm{b}}$ & $18.1^{\mathrm{a}}$ \\
\hline & Metallic & $10.6^{\mathrm{b}}$ & $9.8^{\mathrm{b}}$ & $11.7^{\mathrm{b}}$ & $17.4^{\mathrm{a}}$ \\
\hline & Fish & $7.8^{\mathrm{b}}$ & $7.0^{\mathrm{b}}$ & $13.3^{\mathrm{b}}$ & $34.8^{\mathrm{a}}$ \\
\hline \multirow{5}{*}{ Mouthfeel } & Thick & $73.8^{\mathrm{a}}$ & $32.5^{\mathrm{c}}$ & $50.6^{\mathrm{b}}$ & $38.3^{\mathrm{c}}$ \\
\hline & Smooth & $22.2^{\mathrm{b}}$ & $52.5^{\mathrm{a}}$ & $43.0^{\mathrm{a}}$ & $45.1^{\mathrm{a}}$ \\
\hline & Glutenous & $48.4^{\mathrm{a}}$ & $18.3^{\mathrm{c}}$ & $28.3^{\mathrm{b}}$ & $27.1^{\mathrm{bc}}$ \\
\hline & Mouthcoating & $43.3^{\mathrm{a}}$ & $30.4^{\mathrm{b}}$ & $37.2^{\mathrm{ab}}$ & $37.3^{\mathrm{ab}}$ \\
\hline & Mouthdrying & $27.6^{\mathrm{ab}}$ & $21.5^{\mathrm{b}}$ & $27.2^{\mathrm{ab}}$ & $32.4^{\mathrm{a}}$ \\
\hline \multirow{4}{*}{$\begin{array}{l}\text { After } \\
\text { effects }\end{array}$} & Salty & $10.5^{\mathrm{ab}}$ & $8.0^{\mathrm{b}}$ & $9.1^{\mathrm{b}}$ & $12.6^{\mathrm{a}}$ \\
\hline & Metallic & $9.2^{\mathrm{ab}}$ & $5.7^{\mathrm{b}}$ & $8.4^{\mathrm{b}}$ & $13.6^{\mathrm{a}}$ \\
\hline & Salivating & $18.1^{\mathrm{ab}}$ & $13.9^{\mathrm{b}}$ & $17.4^{\mathrm{ab}}$ & $19.8^{\mathrm{a}}$ \\
\hline & Burning & $24.4^{\mathrm{a}}$ & $10.4^{\mathrm{b}}$ & $10.6^{\mathrm{b}}$ & $8.5^{\mathrm{b}}$ \\
\hline
\end{tabular}

621 Attributes were no significant differences were found between products were smell : mushroom, chicken, egg, cheese; 622 flavour : butter, egg, cheese; mouthfeel : greasy ; aftereffect : umami 


\begin{tabular}{|c|c|c|c|c|c|}
\hline & & $\begin{array}{c}\text { Macronutrient } \\
\text { fortified }\end{array}$ & $\begin{array}{c}\text { Macronutrient \& } \\
\text { Flavour } \\
\text { Enhancer }\end{array}$ & $\begin{array}{c}\text { Macronutrient } \\
\& \\
\text { Micronutrient }\end{array}$ & $\begin{array}{c}\text { Macronutrient \& } \\
\text { Micronutrient \& } \\
\text { Flavour Enhancer }\end{array}$ \\
\hline \multirow{2}{*}{ Appearance } & Brown & $55.4^{\mathrm{b}}$ & $41.5^{\mathrm{c}}$ & $66.3^{\mathrm{a}}$ & $49.8^{\mathrm{b}}$ \\
\hline & Oily & $21.5^{\mathrm{ab}}$ & $28.9^{\mathrm{a}}$ & $20.3^{\mathrm{b}}$ & $27.4^{\mathrm{ab}}$ \\
\hline \multirow{9}{*}{ Smell } & Caramel & $14.3^{\mathrm{a}}$ & $5.3^{\mathrm{b}}$ & $7.2^{\mathrm{b}}$ & $7.7^{\mathrm{b}}$ \\
\hline & Savoury & $29.3^{\mathrm{b}}$ & $31.0^{\mathrm{b}}$ & $40.7^{\mathrm{a}}$ & $30.8^{\mathrm{b}}$ \\
\hline & Mushroom & $23.1^{\mathrm{ab}}$ & $31.8^{\mathrm{a}}$ & $17.0^{\mathrm{b}}$ & $25.5^{\mathrm{ab}}$ \\
\hline & Onion & $12.6^{\mathrm{b}}$ & $10.1^{\mathrm{b}}$ & $20.3^{\mathrm{a}}$ & $12.7^{\mathrm{b}}$ \\
\hline & Chicken & $12.4^{\mathrm{ab}}$ & $15.5^{\mathrm{a}}$ & $7.7^{\mathrm{b}}$ & $13.5^{\mathrm{ab}}$ \\
\hline & Beef stock & $16.7^{\mathrm{ab}}$ & $10.1^{\mathrm{b}}$ & $26.3^{\mathrm{a}}$ & $13.4^{\mathrm{b}}$ \\
\hline & Red wine & $4.4^{\mathrm{b}}$ & $0.8^{\mathrm{b}}$ & $26.7^{\mathrm{a}}$ & $6.6^{\mathrm{b}}$ \\
\hline & Buttery & $21.2^{\mathrm{a}}$ & $14.5^{\mathrm{ab}}$ & $12.1^{\mathrm{b}}$ & $11.3^{\mathrm{b}}$ \\
\hline & Acidic & $8.0^{\mathrm{b}}$ & $8.1^{\mathrm{b}}$ & $16.3^{\mathrm{a}}$ & $9.7^{\mathrm{b}}$ \\
\hline \multirow{4}{*}{ Taste } & Acidic & $12.3^{\mathrm{bc}}$ & $10.4^{\mathrm{c}}$ & $26.0^{\mathrm{a}}$ & $18.4^{\mathrm{b}}$ \\
\hline & Bitter & $13.4^{\mathrm{b}}$ & $20.1^{\mathrm{ab}}$ & $24.4^{\mathrm{a}}$ & $26.7^{\mathrm{a}}$ \\
\hline & Salty & $22.1^{\mathrm{b}}$ & $23.0^{\mathrm{b}}$ & $31.0^{\mathrm{a}}$ & $30.5^{\mathrm{a}}$ \\
\hline & Umami & $29.3^{\mathrm{b}}$ & $29.3^{\mathrm{b}}$ & $37.0^{\mathrm{a}}$ & $33.4^{\mathrm{ab}}$ \\
\hline \multirow{6}{*}{ Flavour } & Creamy & $17.8^{\mathrm{a}}$ & $14.7^{\mathrm{ab}}$ & $10.8^{\mathrm{b}}$ & $12.5^{\mathrm{b}}$ \\
\hline & Buttery & $25.5^{\mathrm{a}}$ & $18.1^{\mathrm{ab}}$ & $18.5^{\mathrm{ab}}$ & $16.1^{\mathrm{b}}$ \\
\hline & Beef & $17.6^{\mathrm{b}}$ & $11.1^{\mathrm{b}}$ & $29.2^{\mathrm{a}}$ & $17.4^{\mathrm{b}}$ \\
\hline & Mushroom & $17.8^{\mathrm{b}}$ & $32.6 \mathrm{a}$ & $15.7^{\mathrm{b}}$ & $32.8^{\mathrm{a}}$ \\
\hline & Nutty & $5.2^{\mathrm{ab}}$ & $11.6^{\mathrm{a}}$ & $1.8^{\mathrm{b}}$ & $10.9^{\mathrm{a}}$ \\
\hline & Red wine & $4.9^{\mathrm{b}}$ & $2.1^{\mathrm{b}}$ & $26.5^{\mathrm{a}}$ & $8.7^{\mathrm{b}}$ \\
\hline \multirow{4}{*}{ Mouthfeel } & Greasy & $30.1^{\mathrm{a}}$ & $33.5^{\mathrm{a}}$ & $23.0^{\mathrm{b}}$ & $28.5^{\mathrm{ab}}$ \\
\hline & Smooth & $52.2^{\mathrm{a}}$ & $40.8^{\mathrm{b}}$ & $55.2^{\mathrm{a}}$ & $41.8^{\mathrm{b}}$ \\
\hline & Rich & $28.9^{\mathrm{b}}$ & $25.6^{\mathrm{b}}$ & $40.6^{\mathrm{a}}$ & $30.8^{\mathrm{b}}$ \\
\hline & Starchy & $12.2^{\mathrm{ab}}$ & $14.4^{\mathrm{a}}$ & $10.5^{\mathrm{b}}$ & $11.8^{\mathrm{ab}}$ \\
\hline \multirow{4}{*}{$\begin{array}{l}\text { After } \\
\text { effects }\end{array}$} & Salty & $15.8^{\mathrm{b}}$ & $19.6^{\mathrm{b}}$ & $30.5^{\mathrm{a}}$ & $33.9^{\mathrm{a}}$ \\
\hline & Sweet & $19.8^{\mathrm{ab}}$ & $13.5^{\mathrm{b}}$ & $21.4^{\mathrm{a}}$ & $17.1^{\mathrm{ab}}$ \\
\hline & Sour & $4.8^{\mathrm{b}}$ & $9.3^{\mathrm{ab}}$ & $12.6^{\mathrm{a}}$ & $10.3^{\mathrm{ab}}$ \\
\hline & Mushroom & $14.5^{\mathrm{b}}$ & $26.3^{\mathrm{a}}$ & $13.6^{\mathrm{b}}$ & $27.7^{\mathrm{a}}$ \\
\hline
\end{tabular}

$625 \quad{ }^{a b c}$ Mean values with the same letter within the same row are not significantly different at $\mathrm{p}<0.05$

626 Attributes where no significant differences were found between products were appearance: thick, opaque, bits; smell :

627 fatty, starchy, boiled vegetables, nutty; taste: sweet; flavour: acidic, meat, burnt caramel; mouthfeel: mouthcoating,

628 gritty, dry

629

630 